states as follows: "When the nitro-benzol is to be sold as 'mirbane' it is distilled under diminished pressure in order to obtain a perfectly clear and transparent liquid such as the users of myrbane demand. It is customary to use toluene imperfectly freed from benzene for this purpose, that article being cheaper and yielding a somewhat more fragrant myrbane than benzene alone." In Poisons: their Effects and Detection, by A. and M. Wynter Blyth, it is stated that 1 gram (15.4 grains) would probably be sufficient to kill an adult, and that spirituous liquids especially hasten and intensify the action of nitro-benzene, so that a drunken person, caeteris paribus, taking the poison with spirits would be more affected than taking it under other conditions. In one case which occurred in Vienna a woman who took about three and a half ounces, and was admitted into hospital in a highly cyanotic condition with small pulse and superticial respiration, eventually recovered. It is stated that the more characteristic pathological appearances seem to be dark brown or even black colour of the blood, which coagulates with difficulty, venous hyperaemia of the brain and its membranes, and general venous engorgement. The blood gives the spectrum of acid haematin; its power of carrying and imparting oxygen to the tissues is diminished, and its content of carbon dioxide increased. It is further stated that on drinking the poison there is a burning taste in the mouth shortly followed by very striking blue or purple appearance of the lips, tongue skin, nails, and even the conjunctivae. Discoloration may precede vomiting by as long as an hour; the skin becomes cold, there is great depression, the pulse is small and weak, and the breathing slow and irregular; this is followed by the sudden development of unconsciousness, and the whole condition may closely resemble apoplectic coma. The shortest period mentioned in which nitrobenzene has caused death is four or five hours. Inhala. tion of the vapour of nitro-benzene produces symptoms similar to those of alcoholic intoxication deepening into a coma. "Benzene Collas" used to be, and perhaps still is, a very popular domestic application for taking grease spots out of cloth.

\section{MOTOR CARS FOR MEDICAL MEN.} \section{A FEW SIMPLE AND USEFUL CALCULATIONS FOR} MOTORISTS.

By R. Bruce Ferguson, M.A., M.D.Cantab., D.P.H.

IN these days when so many motorists are their own chauffeurs, and even mechanics, it is always interesting and often useful to compare notes with one's friends regarding the expenses, actual performances, or potential possibilities of one's car. To enable one to do so satis factorily figures are essential, and for this purpose a few simple examples are given below, in the hope they may prove of some slight assistance.

Horse Power and Insurance Premiums.

A few years ago a friend purchased a small car. The makers' rating was 8-h.p., and at this figure he insured it He afterwards discovered that he might have exercised the option of selecting either the makers' rating or the R.A.C. (Treasury) rating, which is calculated according to the following formula:

$$
\text { H.P. }=\frac{d^{2} \times n}{2.5}
$$

where $d=$ diameter of cylinder in inches, and $n=$ number of cylinders.

In his case the number of cylinders was 2, and their diameter $75 \mathrm{~mm}$., and taking the usually-adopted computa. tion of $25 \mathrm{~mm}$, to the inch, he estimated the horse-power as $\frac{(3)^{2} \times 2}{2.5}=7.2$, and insured his car the next year as a 7-h.p., thus saving 8s. Before his next premium was due I pointed out to him that his inaccurate assumption of $25 \mathrm{~mm}$. making an inch was costing him annually more than the price of his driver's licence, and that the correct figure was $1 \mathrm{~mm}$. $=0.03937$ inch. The formula thus becomes :

$$
\frac{(0.03937 \times d)^{2}}{2.5} \times n \text { where } d=\text { diameter in millimetres. }
$$

When simplified this will read : $\frac{d^{2} \times n}{1613}$

The horse-power of his car is therefore $\frac{(75)^{2} \times 2}{1613}=6.98$.

Since the insurance company neglects fractions of a horse- power, he now insures it as a 6-h.p. car, and saves a further sum of $6 \mathrm{~s}$. every year.

\section{Ton-miles per Gallon.}

The comparison of the merits of two cars by the number of miles they will run on a gallon of petrol is not an entirely satisfactory method, since it fails to take into account the weight of the car, accessories, and passengers. It is better to estimate the number of ton-miles per gallon.

If $P=$ weight in pounds of car, accessories, and passengers, $M=$ the number of miles run, and $G=$ the number of gallons of petrol used, then $\mathbf{P} \times \mathbf{M}=$ the number of pound-miles, and $\frac{P \times M}{2 \angle 4 U}=$ the number of ton-miles obtained from $G$ gallons,

and $\frac{P \times M}{2240 \times G}=$ the number of ton-miles per gallon.

Volume Swept Out by the Pistons at Each Revolution.

This is simply the estimation of the cubic contents of that portion of the cylinder in which the piston moves.

If $d=$ diameter of cylinder in millimetres, and $s=$ length of piston-stroke in millimetres, then the sectional area of the cylinder will be $d^{2} \times 0.7854$ square $\mathrm{mm}$., and the cabic contents will be $d^{2} \times 0.7854 \times s$ cubic mm., or

$$
\begin{aligned}
& \frac{d^{2} \times 0.7854 \times 8}{1000} \text { cubic centimetres, or } \\
& \frac{d^{2} \times 0.7854 \times 8 \times 0.061}{1000} \text { cubic inches. }
\end{aligned}
$$

The latter may also be expressed as $d^{2} \times 8 \times 0.000048$ cubic inches.

To obtain the total volume, multiply finally by the number of cylinders.

A Problem in Tyre Sizes.

As the matter of tyre sizes is one which, to my knowledge, pazzles many a motorist, an example on the subject may not be deemed out of place.

One very hot summer's day I found a friend making heroic but ineffectual attempts to place upon a front wheel a tyre which he had just removed from a back one. It was then discovered that the tyre previously on the front was a $30 \times 3$ in., whilst the back tyre, which it was now wished to place on the front, was a $30 \times 3 \frac{1}{2}$ in. It was argued that the latter should go on the front wheel easily, since it was the larger tyre; but therein lies the fallacy, for it is only larger in the sense that it will hold more air, the sectional areas of the two tyres varying as the squares of their diameters, namely:

$$
\text { As }(3)^{2}:\left(3 \frac{1}{2}\right)^{2} \text {; or as } 36: 49 .
$$

The larger tyre thus holds 36 per cent. more air than the smaller. In other respects, however, the $3 \frac{1}{1}$ in, tyre is smaller than the 3 in., as can be easily demonstrated. A " 30 inch tyre" means that when the tyre is on the wheel and fully inflated, a vertical line dropped from the highest point of the tyre to the ground measures $30 \mathrm{in.}$. If the depth of the tyre be 3 in. at the top and 3 in. at the bottom, the diameter of the wheel itself (without the tyre) measured from rim to rim will be $30-(2 \times 3)=24$ in. If, however, the depth of the tyre be $3 \frac{1}{2}$ in., the wheel itself can only have a diameter of $30-\left(2 \times 3 \frac{1}{2}\right)=23$ in., and on actual measurement this was shown to be the case, the back wheel being the smaller of the two. The failure of the effort was thus due to the attempt to place npon a 24-in. wheel a tyre which was made for a 23-in. wheel.

It will be readily seen that a $710 \times 90 \mathrm{~mm}$. tyre can replace a $700 \times 85 \mathrm{~mm}$., since in each case the rim-to-rim diameter will be $530 \mathrm{~mm}$.

For example, $710-(90 \times 2)=530$ in the former, and $700-$ $(85 \times 2)=530$ in the latter.

Similarly, $760 \times 90$ is interchangeable with $750 \times 85$, and also $810 \times 90$ with $800 \times 85$

The fact that it is occasionally possible to stretch a tyre on to a wheel slightly too large for it does not in any way affect the accuracy of the explanation given above.

THE National Health Society, 53, Berners Street, has recently issued a kind of poster, price ld., containing a series of hints in regard to keeping houses and their inhabitants healthy. Recollection of them is facilitated by their being given in rhymed verse, and with one single exception the statements made all seem undeniably sound; while, in respect both of rhythm and rhyme, the author, "F. L.," is fully entitled to hold up his head in the company of the minor poets of the age. 